\title{
Rumen papillae keratinization, cell glycogen and chemical composition of the meat from young bulls fed different levels of concentrate and babassu mesocarp bran
}

\author{
Queratinização das papilas ruminais, glicogênio celular e \\ composição química da carne de tourinhos alimentados com níveis \\ de concentrado e farelo do mesocarpo do babaçu
}

\author{
Simone Santos Barros ${ }^{1}$; Rossini Sôffa da Cruz²; Lázaro Moreira de Melo Junior ${ }^{3}$; \\ Domenica Palomaris Mariano de Souza ${ }^{4}$; Sandro Estevan Moron ${ }^{4}$; Emerson \\ Alexandrino ${ }^{4}$; Regis Luis Missio ${ }^{5 *}$; José Neuman Miranda Neiva ${ }^{4}$; João Restle ${ }^{6}$; \\ Viviane Mayumi Maruo ${ }^{4}$; Luciano Fernandes Sousa ${ }^{4}$; Adriano Tony Ramos ${ }^{4}$
}

\begin{abstract}
This study aimed to assess the rumen papillae keratinization, cellular levels of liver and muscle glycogen, and the chemical composition of meat from feedlot-finished Nellore young bulls fed with levels of concentrate and babassu mesocarp bran. Twenty-eight animals with initial age of 21 months and initial body weight of $356.7 \pm 19 \mathrm{~kg}$ were randomized to the following treatments: two levels of concentrate in the diet $(65 \%$ and $71 \%)$, with or without inclusion of $35 \%$ of babassu mesocarp bran. Fragments of liver, muscle and rumen were obtained after slaughter of the animals. Levels of concentrate and babassu mesocarp bran in the diet did not affect the quantities of liver and muscle glycogen, and did not induce hyperkeratinization of rumen papillae. The chemical composition of the meat was not affected by the studied factors. The inclusion of $35 \%$ babassu mesocarp bran in high concentrate diets does not induce hyperkeratinization of rumen papillae, and does not change the amount of muscle and liver glycogen or the chemical characteristics of meat of Nellore young bulls.
\end{abstract}

Key words: Biodiesel, beef cattle, liver, hyperkeratinization, rumen papillae

\section{Resumo}

Objetivou-se avaliar a queratinização das papilas ruminais, o nível celular de glicogênio hepático e muscular, e a composição química da carne de tourinhos Nelore terminados em confinamento alimentados com níveis de concentrado e farelo do mesocarpo do babaçu. Foram utilizados 28 animais, com idade

1 Discente do Curso de Mestrado em Ciência Animal Tropical, Escola de Medicina Veterinária e Zootecnia, Universidade Federal do Tocantins, UFT, Araguaína, TO, Brasil. E-mail: simoneesb@gmail.com

2 Discente do Curso de Doutorado em Ciência Animal Tropical, Escola de Medicina Veterinária e Zootecnia, UFT, Araguaína, TO, Brasil. E-mail: rossinizoot@hotmail.com

3 Discente do Curso de Graduação em Medicina Veterinária, Escola de Medicina Veterinária e Zootecnia, UFT, Araguaína, TO, Brasil. E-mail: 1jmedvet@gmail.com

4 Profs., Escola de Medicina Veterinária e Zootecnia, UFT, Araguaína, TO, Brasil. E-mail: domenica.palomaris@gmail.com; sandromoron@uol.com.br; e_alexandrino@yahoo.com.br; araguaia2007@gmail.com; vivimaruo@uft.edu.br; luciano.sousa@ mail.uft.edu.br; adrianotony@yahoo.com.br

5 Prof., Depto de Agronomia, Universidade Tecnológica Federal do Paraná, UTFPR, Pato Branco, PR, Brasil. E-mail: regisluismissio@gmail.com

6 Bolsista PVNS CAPES, Escola de Medicina Veterinária e Zootecnia, UFT, Araguaína, TO, Brasil. E-mail: jorestle@terra.com.br

* Author for correspondence 
inicial de 21 meses e peso corporal inicial de $356,7 \pm 19 \mathrm{~kg}$, distribuídos inteiramente ao acaso nos seguintes tratamentos: dois níveis de concentrado na dieta $(65 \%$ e $71 \%)$ associados ou não à inclusão de $35 \%$ de farelo do mesocarpo do babaçu. Fragmentos do fígado, músculo e rúmen foram obtidos após abate dos animais. Os níveis de concentrado e de farelo do mesocarpo do babaçu da dieta não alteraram as quantidades de glicogênio hepático e muscular, bem como não induziram a hiperqueratinização das papilas ruminais. A composição química da carne não foi alterada pelos fatores estudados. A inclusão de 35\% de farelo do mesocarpo do babaçu em dietas com elevada proporção de concentrado não induz a hiperqueratinização das papilas ruminais, bem como não altera a quantidade de glicogênio muscular e hepático e, as características químicas da carne de tourinhos Nelore.

Palavras-chave: Biodiesel, bovino de corte, fígado, hiperqueratinização, papila ruminal

\section{Introduction}

The increase in the world population and the elevation in income, notably in the developing countries, have determined increase in the demand for beef, leading to the need to improve productivity of the herds. In this context, Brazil plays an important role in the international market, since, as opposed to the main producing countries, it has real chances of increasing production. This is due to the Brazilian large cattle herd, the available pasture areas and the favorable soil and climate conditions for forage production. Associated to these factors are the low productivity rates, which are a result of the inappropriate reproductive, sanitary and nutritional management, as well as the low genetic potential of the herd.

As regards the nutritional aspects, the main measures to increase herd productivity involve recovery of degraded pasture areas, adjustment of the stocking rate, mineral supplementation, and improvement of the environmental conditions with regard to animal welfare. Some other important measures are pasture management, nitrogen fertilization of the pastures, strategic nutritional supplementation and irrigation of the pastures during the dry season, and the use of feedlot.

The feedlot, in this scenario, shows great importance given its high impact on the offtake rate, and consequently, on the productivity of the production system. This management strategy, during the dry period of the year, enables the slaughter of animals in the off-season, with better commercialization price for the product. The improvement in the commercialization price may also stem from reduction in the slaughter age of animals. Indirectly, the feedlot enables clearing the pasture areas for other categories, which thereby allows adjusting the stocking rate and consequently improving the nutritional management, as well as provides better reproductive indices and increased support capacity of the farm. This strategy can be adopted also as a pasture-management tool, inasmuch the excess forage is stored, preventing qualitative losses caused by the advance of the plant productive cycle, and thus enabling new pasture regrowth, which in turn favors production and forage quality due to the improvement in the forage-sward structural conditions and conditions of competition for luminosity.

Despite the benefits, the use of feedlot may present low profit margin, notably due to the elevation of the costs with feeding, resulting from the increase in the price of cereal grains, especially the corn. In addition to this, due to the need for appropriate nutrient uptake for finishing cattle and the difficulty to produce preserved forages of high nutritional value, grain-based diets have been preferred, and this increases the concern about the economic feasibility of this management strategy. These diets, however, have been utilized as options for the farms with low agricultural aptitude and/ or commercial feedlots (difficulty to produce preserved forages), and their benefits are attributed to the elevated animal performance, fat cover and carcass yield, lower risk with forage production and decrease in the production costs from reduction in the operational costs. Nevertheless, these arguments are 
not unanimous, since the production cost is elevated by increase in the proportion of concentration in the diet (RODRIGUES FILHO et al., 2002).

In an attempt to make the use of feedlot possible, efforts have been put together to develop alternative low-cost foods that may totally or partially replace the corn grain in the diet. Babassu mesocarp bran, originating from the processing of the fruit of the babassu palm tree (Orbygnya sp.), has a starch content of 52\% (PAVLAK et al., 2007), which has made this by-product an option in animal feeding. Silva et al. (2012) verified that inclusion of levels of this by-product $(0 \%, 20 \%, 40 \%$ and $60 \%)$ in the diet of Nellore young bulls or Nellore steers did not change animal performance. However, Miotto et al. (2012) verified that the weight and carcass fat cover reduced with the presence of elevated levels of babassu mesocarp bran in the diet $(0 \%, 25 \%$, $50 \%, 75$ and $100 \%$ ) of $1 / 2$ Nelore $\times 1 / 2$ Brown Swiss young bulls finished in feedlot. These researchers also verified reduced tenderness and increased mineral content in the meat caused by elevation in the babassu mesocarp bran, which may be linked to the deposition of insoluble collagen and to the higher mineral content of this by-product in relation to the corn grain.

Most studies conducted with babassu mesocarp bran in diets for cattle utilized diets with low-tomoderate proportions of concentrate. In these cases, the inclusion of babassu mesocarp bran may limit the energy uptake of the diets, both by the energy content of this by-product in relation to the corn grain and by the restriction of intake due to the roughage content of the diet (physical limitation of intake). This may result in alterations in the meat quality, as it may change the deposition of the tissues in the carcass, as well as the chemical composition (DI MARCO; BARCELLOS; COSTA, 2007). The scarce deposition of fat in the carcass may also reduce the protection of the carcass against the cold, causing the muscle fibers to shorten (FELÍCIO, 1997). Furthermore, the low energy uptake of the diet, associated with the reactive temper of the animals, may result in depletion of muscle glycogen content, affecting the meat properties (MARÍA et al., 2003; CAFE et al., 2011). On the other hand, in diets with elevated proportions of concentrate, the use of babassu mesocarp bran may favor the rumen environment due to the lower nonfibrous carbohydrate content in relation to the corn grain (CRUZ et al., 2012), which may reduce the incidence of metabolic disorders and favor animal performance, which may result in changes of the tissue composition of the carcass, as well as the chemical composition of the meat.

Given the above, the objective of this study was to evaluate the keratinization of the rumen papillae, the cellular level of liver and muscle glycogen and the chemical composition of the meat from feedlotfinished young bulls fed levels of concentrate and babassu mesocarp bran.

\section{Material and Methods}

The experiment was conducted at Escola de Medicina Veterinária e Zootecnia, in the Universidade Federal do Tocantins (UFT), Campus Araguaína, located at $07^{\circ} 11^{\prime} 28^{\prime \prime}$ south latitude $48^{\circ} 12^{\prime} 26^{\prime \prime}$ west longitude. Twenty-eight Nellore young bulls weaned at seven months of age and grown on a Brachiaria brizantha cv. Marandu pasture with mineral supplementation, presenting 21 months of age and $356.66 \pm 19.25 \mathrm{~kg}$ body weight at the beginning of the experiment were used. They were confined in individual partially covered pens $\left(14 \mathrm{~m}^{2}\right)$ provided with individual water and feed troughs. Animals were pre-adapted for $15 \mathrm{~d}$ to the level of inclusion of the concentrate in the diet and to the feeding management. Afterwards, the animals were distributed over the experimental diets (Table 1), having seven days to adapt to the facilities. Diets were formulated to contain the same amount of protein $(12.3 \%)$, considering an intake of $2.4 \%$ of the body weight (NRC, 1996) and a roughage proportion according to the concentrate level desired. The present study was approved by CEUA/ UFT, process $n^{\circ}$. 23101.003910/2012-53. 
Table 1. Centesimal and chemical composition of the experimental diets.

\begin{tabular}{|c|c|c|c|c|}
\hline \multirow{2}{*}{$\%$ of DM } & \multicolumn{4}{|c|}{ Diets } \\
\hline & 65C/0BMB & 71C/0BMB & $65 \mathrm{C} / 35 \mathrm{BMB}$ & $71 \mathrm{C} / 35 \mathrm{BMB}$ \\
\hline \multicolumn{5}{|c|}{ Centesimal composition of the diet (\% of dry matter) } \\
\hline Silage of Brachiaria brizanta cv. Piatã & 35.00 & 29.00 & 35.00 & 29.00 \\
\hline Babassu mesocarp bran & -- & -- & 22.68 & 25.46 \\
\hline Ground corn grain & 54.97 & 62.80 & 32.46 & 36.74 \\
\hline Soybean bran & 7.49 & 5.80 & 6.67 & 5.70 \\
\hline Urea (for livestock) & 0.91 & 0.88 & 1.51 & 1.50 \\
\hline Calcitic limestone & 0.82 & 0.78 & 0.81 & 0.77 \\
\hline Mineral mixture ${ }^{*}$ & 0.51 & 0.44 & 0.51 & 0.48 \\
\hline Common salt & 0.21 & 0.20 & 0.20 & 0.19 \\
\hline Ammonium sulfate & 0.09 & 0.10 & 0.17 & 0.17 \\
\hline \multicolumn{5}{|c|}{ Chemical composition of the diet ( $\%$ of dry matter) } \\
\hline Dry matter, $\%$ & 70.00 & 72.67 & 70.10 & 72.80 \\
\hline Mineral matter & 5.98 & 5.52 & 7.08 & 6.77 \\
\hline Crude protein & 12.46 & 12.00 & 12.58 & 12.24 \\
\hline NDFap & 28.43 & 24.86 & 32.88 & 29.85 \\
\hline Total digestible nutrients & 73.84 & 76.04 & 67.33 & 68.69 \\
\hline Digestibility of the dry matter & 87.00 & 86.00 & 78.00 & 78.00 \\
\hline
\end{tabular}

$65 \mathrm{C}$ and $71 \mathrm{C}=65 \%$ and $71 \%$ of concentrate $(\mathrm{C})$ in the diet; $0 \mathrm{BMB}$ and $35 \mathrm{BMB}=0 \%$ and $35 \%$ of babassu mesocarp bran (BMB) in the concentrate; NDFap = neutral detergent fiber corrected for the residual ash and protein; ${ }^{*} 118$ and $90 \mathrm{~g} \mathrm{~kg}{ }^{-1}$ of Ca and $\mathrm{P}$, respectively.

Source: Elaboration of the authors.

The feed supply was maintained at $10 \%$ above the voluntary ingestion, and it was adjusted daily by weighing the leftovers from the previous day. The diets were supplied daily at $08 \mathrm{~h} 00$ and $14 \mathrm{~h} 00$, with a mixture of the roughage and the concentrate in the trough. The roughage feed utilized was Brachiaria brizantha $\mathrm{cv}$. Piatã silage cut at the initial stage of flowering, presenting a particle size between 2 and 3 $\mathrm{cm}$, and dry matter, crude protein, neutral detergent fiber and total digestible nutrients contents of $40.0 \%$, $5.6 \%, 28.4 \%$ and $56.0 \%$, respectively. The babassu mesocarp bran was commercially obtained by grinding the mesocarp of babassu fruit until $96 \%$ of particles were smaller than $1.18 \mathrm{~mm}$ in diameter (Penn State Particle Size Separator) and high dustiness was reached, presenting dry matter, crude protein, neutral detergent fiber and total digestible nutrients contents of $85.5 \%, 3.2 \%, 31.6 \%$ and $61.5 \%$.

To determine the chemical composition of the diets, samples of the feeds were collected weekly, labeled, identified and frozen at $-20{ }^{\circ} \mathrm{C}$. After the end of the experiment, these samples were defrosted and a composite sample was formed per period. The samples were pre-dried in a forced air-circulation oven at $55{ }^{\circ} \mathrm{C}$ for $72 \mathrm{~h}$ and processed in a knife mill with a particle size of $1 \mathrm{~mm}$. The levels of dry matter, mineral matter and crude protein were determined according to the AOAC (1995). The neutral detergent fiber content was determined according to Van Soest, Robertson and Lewis (1991); the neutral detergent fiber was corrected for residual ash and protein. The total digestible nutrients content was determined according to Sniffen et al. (1992), in which: total digestible nutrients = total carbohydrates intake - total carbohydrates in the feces + crude protein intake - crude protein in the feces $+(2.25 *$ ether extract intake - ether extract in the feces), total digestible nutrients $(\%)=$ total digestible nutrients intake/dry matter intake, total carbohydrates $=100-($ crude protein + ether extract + mineral matter + neutral detergent fiber $)$ and non- 
fibrous carbohydrates $=100-($ total carbohydrates + neutral detergent fiber).

The digestibility trial was conducted on three consecutive days, by manually collecting $300 \mathrm{~g}$ of feces during spontaneous defecation. These samples were processed and analyzed for the contents of dry matter, mineral matter, neutral detergent fiber and non-fibrous carbohydrates as previously mentioned. The fecal dry matter output was estimated with the internal-marker technique (COCHRAN et al., 1986), adopting the indigestible neutral detergent fiber (iNDF) as the marker. The iNDF content of the samples of feces, feed and leftovers was obtained after in situ incubation performed in two crossbred (dairy) cows fed similar diets for $240 \mathrm{~h}$ (CASALI et al., 2008). The fecal output (FO) was determined by the formula: FO $\left(\mathrm{kg}\right.$ dry matter day $\left.{ }^{-1}\right)=(\mathrm{iNDF}$ intake/concentration of iNDF in the feces) $\times 100$. The apparent digestibility was determined by the formula: Apparent digestibility $(\%)=[$ (nutrient intake - nutrient excreted)/nutrient intake] $\times 100$.

After $77 \mathrm{~d}$ of confinement, when animals reached the minimum weight required by the slaughterhouses of the region $(460 \mathrm{~kg})$, they were slaughtered at a commercial slaughterhouse with Federal Inspection Service (Serviço de Inspeção Federal, SIF), after a solid and liquid deprivation period of 12-14 h. After the slaughter, the carcasses were identified, divided in half, weighed, washed and taken to a cold chamber for $24 \mathrm{~h}$ at a temperature varying between 0 and $2{ }^{\circ} \mathrm{C}$. During slaughter, fragments of the rumen and liver were collected and frozen for subsequent processing.

In the cold carcasses, a sample of the longissimus dorsi muscle was collected between the 11th and the 12 th ribs of the right carcass, packed, identified and frozen at $-18^{\circ} \mathrm{C}$. Fragments of organs like the liver and rumen (portion of the caudal dorsal blind sac) were washed in saline solution and fixed in Bouin solution. After fixation, the tissue was dehydrated in increasing ethanol series embedded in paraffin and cut to a thickness of $3 \mu \mathrm{m}$. To identify and visualize the glycogen, the slides were subjected to the Periodic Acid Schiff (PAS) protocol as described by Yashpal et al. (2007). To evaluate the keratin, was carried out the morphometry of the rumen sections stained by Hematoxylin-eosin. Readings were performed on five areas for each microscopic slide of liver assessed. The morphological analysis was conducted by evaluating the presence of glycogen per metabolic region and circulatory area, with binocular microscope Leica DM 500 under 400X magnification coupled to a ICC 50 HD camera. The software Leica Application Suite EZ (LASEZ) version 2.0 was utilized to capture the images, which were analyzed by Image Tool 3.0 program. The positive PAS area of five lobules randomly chosen in transversal sections of each slide was analyzed for the estimate. The liver and muscle glycogen was quantified also by tissue biochemistry. For this purpose, $200 \mathrm{~g}$ of longissimus dorsi muscle, disregarding the fat cover, and $200 \mathrm{mg}$ of the liver, were placed in a test tube containing $2 \mathrm{~mL} \mathrm{KOH}$ at $30 \%$, according to the method described by Handel (1965). The ether extract of the liver was determined according to the AOAC (1995).

The thickness of the keratin layer of the ruminal epithelium was determined by measurements using an eyepiece micrometer on an optical microscope with 400X magnification. Each animal had ten measurements performed on them, at random points of the mucosa of the papillary lining epithelium.

The samples of the longissimus dorsi muscle for chemical analysis were defrosted at room temperature, disregarding the fat cover, dried in a forced air-ventilated oven $\left(55^{\circ} \mathrm{C}\right)$ and ground in a Willey mill (1 $\mathrm{mm}$ particle). In the samples of these steaks, the moisture, mineral matter, crude protein and ether extract contents were determined according to the AOAC (1995).

The experimental design utilized was completely randomized, with four treatments and seven replications. The data were subjected to analysis of normality and homogeneity of variances. After 
these assumptions were met, the data were subjected to variance analysis and means were compared by Tukey's test. When the normality assumptions were not met, the means were compared by the KrusKalWallis test, considering $5 \%$ as the critical level of significance.

\section{Results and Discussion}

The results regarding animal performance, carcass and meat characteristics were published in Cruz et al. (2014, 2015a, 2015b), respectively. No interaction was verified between levels of concentrate and babassu mesocarp bran on the evaluated variables (Table 2).

Table 2. Variables referring to the keratinization of ruminal papillae, liver and muscle glycogen, liver ether extract and chemical composition of the meat from Nellore young bulls fed levels of concentrate and babassu mesocarp bran (BMB).

\begin{tabular}{|c|c|c|c|c|}
\hline \multirow{2}{*}{ Variables } & \multicolumn{4}{|c|}{ Diets } \\
\hline & 65C-0BMB & 71C-0BMB & $65 \mathrm{C}-35 \mathrm{BMB}$ & $71 \mathrm{C}-35 \mathrm{BMB}$ \\
\hline \multicolumn{5}{|c|}{ Histomorphometric evaluation of rumen papillae and liver } \\
\hline Keratinization of rumen papillae $(\mu \mathrm{m})^{2}$ & 4.00 & 4.46 & 3.37 & 3.51 \\
\hline Liver glycogen $\left(\mu \mathrm{m}^{2}\right)$ & 5.93 & 6.38 & 6.20 & 6.29 \\
\hline \multicolumn{5}{|c|}{ Biochemical evaluation of the glycogen } \\
\hline Liver glycogen (mg/dL) & 0.14 & 0.16 & 0.14 & 0.19 \\
\hline Muscle glycogen $(\mathrm{mg} / \mathrm{dL})$ & 0.09 & 0.08 & 0.08 & 0.09 \\
\hline \multicolumn{5}{|c|}{ Chemical analysis of the liver } \\
\hline Ether extract $(\%)$ & 11.13 & 11.65 & 11.67 & 12.50 \\
\hline \multicolumn{5}{|c|}{ Chemical analysis of the meat } \\
\hline Dry matter $(\%)$ & 23.14 & 22.68 & 22.23 & 22.13 \\
\hline Mineral matter (\%) & 4.74 & 5.12 & 4.95 & 4.81 \\
\hline Crude protein $(\%)$ & 26.83 & 25.27 & 24.93 & 24.82 \\
\hline Ether extract $(\%)$ & 1.97 & 1.61 & 1.58 & 1.68 \\
\hline
\end{tabular}

$65 \mathrm{C}$ and $71 \mathrm{C}=65 \%$ and $71 \%$ concentrate in the diet, respectively; $0 \mathrm{BMB}$ and $35 \mathrm{BMB}=0 \%$ and $35 \%$ of babassu mesocarp bran $(\mathrm{BMB})$ in the concentrate fraction of the diet; $\mathrm{P}>0.05$.

Source: Elaboration of the authors.

The levels of concentrate and babassu mesocarp bran did not change the keratinization of the ruminal epithelium (Table 2; Figure 1). The intense keratinization of the rumen papillae reduces the absorptive capacity of the epithelium due to reduction in the percentage of metabolically active tissue (CHURCH, 1974), and it is linked to reduction in animal performance during the finishing period (CASTRO; ZANETTI, 1998). Hyperkeratosis is associated with ingestion of diets rich in rapidly fermentable carbohydrates and abrasiveness of the fine particles of the feeds (JENSEN et al., 1954; GREENWOOD et al., 1997). According to Warner, Proter and Slack (1973), to avoid the effect of abrasiveness of the particles on the ruminal epithelium, at least $50 \%$ of the particles of the concentrate should be larger than $1.19 \mathrm{~mm}$. The babassu mesocarp bran, in this sense, presents reduced particle size (MIOTTO et al., 2013), which might compromise the normal rumen activity, be it by ruminal hyperkeratosis and/or by the lower incentive to rumination and rumen buffering. In the present study, considering the particle size of the babassu mesocarp bran $(96 \%$ of particles smaller than $1,18 \mathrm{~mm}$ ), inclusion of $35 \%$ babassu mesocarp bran determined that diets containing $65 \%$ and $71 \%$ of concentrate presented, respectively, $21.8 \%$ and $24.4 \%$ of the particles smaller than $1.18 \mathrm{~mm}$, which partly explains the results obtained. 
Figure 1. Photomicrograph of the rumen from Nellore young bulls fed levels of concentrate (LC) and babassu mesocarp bran (BMB), stained with Keratin layer in pink.

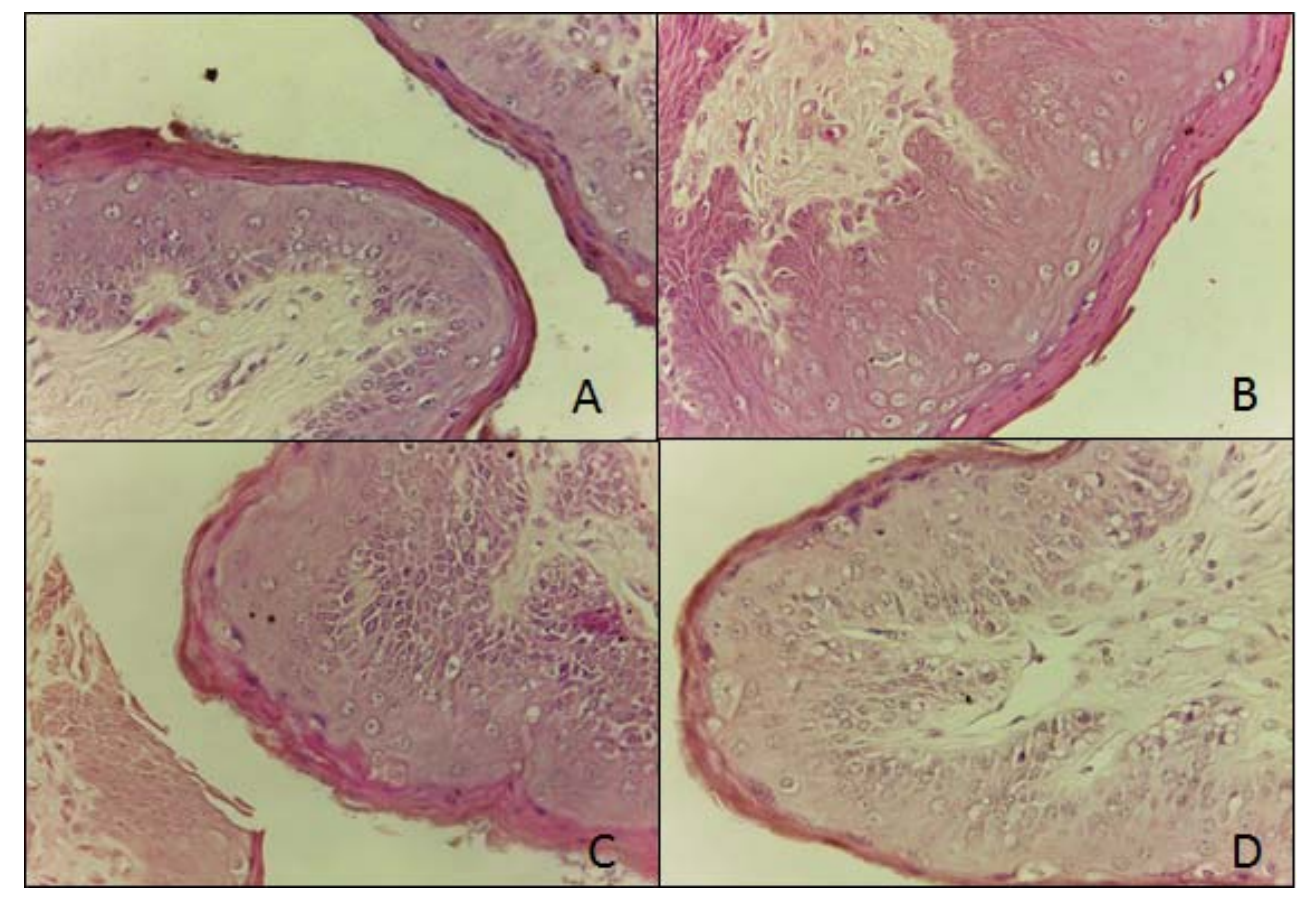

$\mathrm{A}=$ diet with $0 \%$ of $\mathrm{BMB}$ and $65 \%$ of concentrate; $\mathrm{B}=$ diet with $0 \%$ of $\mathrm{BMB}$ and $71 \%$ of concentrate; $\mathrm{C}=$ diet with $35 \%$ of $\mathrm{BMB}$ and $65 \%$ of concentrate; and $\mathrm{D}=$ diet with $35 \%$ of $\mathrm{BMB}$ and $71 \%$ of concentrate. 40X magnification.

Source: Elaboration of the authors.

The evaluated ruminal epithelia were considered normal, with average keratinization of $3.84 \mu \mathrm{m}$, with no cellular injury or degenerative processes detected. Evaluating the ruminal epithelium of 89-day-old calves by infusion of fatty acids for 37 d, Costa et al. (2008) verified that the keratinized areas of the caudo-ventral blind sac were 16.7 $\mu \mathrm{m}, 4.7 \mu \mathrm{m}, 14.9 \mu \mathrm{m}$ and $4.7 \mu \mathrm{m}$ for the butyrate, propionate and saline infusions, respectively. These authors mentioned that saline infusion (control treatment) determined rumen mucosa integrity and regularly outlined papillae; however, infusion of volatile fatty acids determined rumen mucosa and papillae considered non-normal due to the presence of injury and degenerative processes. The smaller area of keratinization of the epithelium, for the infusion of lactate, was explained by increased total area of the epithelium, caused by vacuolation of the epithelial cells; keratinization between infusions of propionate and butyrate was similar.
It is worth noting that intense keratinization of the ruminal epithelium occurs normally when the animal is at its young age, which is the period of greater ruminal development, with greater occurrence in dairy cattle, due to the fact that their feeding is, since early, based on the supply of concentrates. In beef cattle, keratinization of the ruminal epithelium is less common, because calves are reared basically on pasture. Besides, the confinement period in Brazil is utilized mainly for the finishing phase, having short duration. The period of adapt to the diets with elevated concentrate, in this context, is an important feature to avoid digestive disorders such as acidosis and consequent keratinization of the ruminal epithelium. In this period, the ruminal epithelium adapts and the animal improves its capacity to keep the ruminal environment less acid, which is a consequence of the increase in the absorptive surface caused by the growth and ramification of the ruminal papillae, which results 
in lower accumulation of rumen volatile fatty acids (GOODLAD, 1981; RESENDE JÚNIOR et al., 2006).

The macroscopic analysis of the liver showed that there were no changes in the color and texture patterns according to the levels of concentrate and babassu mesocarp bran. Glycogen, under light microscopy, showed as lumps reactive to periodic acid-Schiff (PAS) sparse in the cytoplasm both in the groups fed diets containing different concentrate levels and in those fed diets with or without addition of babassu mesocarp bran (Figure 2). The evaluated areas in each animal revealed heterogeneous and diffuse distribution of glycogen, but with quantities that varied from moderate to discrete, presenting alternatively positive and negative hepatocytes irrespective of the region studied.

Figure 2. Photomicrograph (40X magnification) of livers from Nellore young bulls fed levels of concentrate and babassu mesocarp bran, stained with Periodic Acid Schiff.

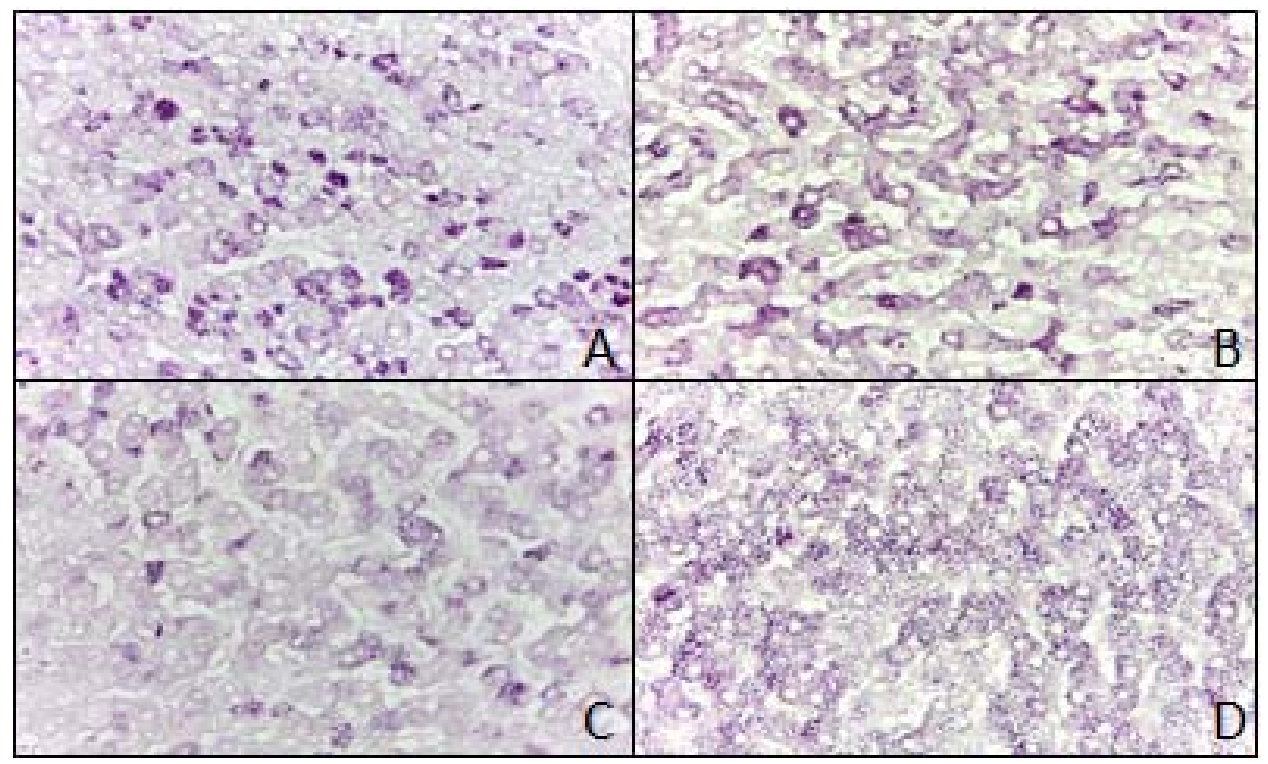

$\mathrm{A}=$ diet with $0 \%$ of babassu mesocarp bran $(\mathrm{BMB})$ and $65 \%$ of concentrate; $\mathrm{B}=$ diet with $0 \%$ of $\mathrm{BMB}$ and $71 \%$ of concentrate; $\mathrm{C}=$ diet with $35 \%$ of $\mathrm{BMB}$ and $65 \%$ of concentrate; and $\mathrm{D}=$ diet with $35 \%$ of $\mathrm{BMB}$ and $71 \%$ of concentrate. Glycogen granules reagent to the Periodic Acid Schiff (PAS) in purple.

Source: Elaboration of the authors.

The quantification of the glycogen by the technique of hystomorphometry did not show alteration of this trait according to the levels of concentrate and babassu mesocarp bran (Table 1). Similar results were verified by the biochemical dosage of the liver glycogen, in which its quantity was not changed by the levels of concentrate and babassu mesocarp bran. The results obtained with the different techniques were moderately associated $(\mathrm{r}=0.55 ; \mathrm{P}=0.01)$, demonstrating the possibility of utilization of both techniques to quantify the liver glycogen. The use of histomorphometry as a complementary technique to biochemistry reveals the location of the glycogen in the cells in the different regions of the liver, which is an aspect of paramount importance, since this organ represents metabolically distinct regions (STALKER; HAYES, 2007).

In a unique study with the use of the babassu byproduct, Henriques et al. (2009) verified reduction 
of liver glycogen in mice fed babassu starch flour, which was attributed to the presence of bioactive substances and soluble and insoluble fibers present in this by-product, which may trigger a discrete glycemic response. In the present study, lower liver glycogen contents were somehow expected in the diets with lower levels of concentrate and in those with inclusion of the babassu mesocarp bran, given that these diets showed lower energy content as a result of the concentrate contents and of the lower energy level of the babassu mesocarp bran in relation to the corn grain (Table 1). Corroborating the hypothesis, Lima et al. (2003) verified that high carbohydrate diets increased the liver glycogen levels significantly, as a consequence of the greater energy uptake by the organism. However, as opposed to the expectations, the similar values of liver glycogen obtained in the present study were partly associated with the similar energy intake (CRUZ et al., 2014). The fact that these animals were deprived of solids and liquids (12-14 h) in the pre-slaughter period, as an experimental requisite to evaluate the carcass and meat characteristics, contributed to these results. This fact probably reduced the liver glycogen levels to the same level, because glycogen is not stored at large amounts in the liver, except in the case of some diseases, in which a reserve is readily available as a result of the constant glyconeogenesis and glycogenolysis, the latter being more marked in the moments of feed deprivation (HALL, 2011).

Muscle glycogen, determined at the longissimus dorsi muscle $24 \mathrm{~h}$ after cooling the carcasses, was not affected by the levels of concentrate and babassu mesocarp bran (Table 2). The glycogen metabolism in the striated muscle takes on great importance for transformation of the muscle into meat, and its concentration in the muscle, moments prior to slaughter, is a determinant of the formation of lactic acid and drop of $\mathrm{pH}$, affecting tenderness, coloration, water retention and causing alterations in the shelf life of the meat (MUCHENJE et al., 2009). The main determinants of muscle glycogen are related to genotype, pre-slaughter stress, the time of transportation to the slaughterhouses, feeding and the interaction between these factors (MARÍA et al., 2003; ALVES et al., 2005; CAFE et al., 2011). The effects of feeding are clearer in diets with low concentrations of digestible carbohydrates and in their association with less docile genotypes and long and stressful fasting periods, which reduces the stocks of muscle glycogen, influencing the meat quality (MARÍA et al., 2003; FERGUSON; WARNER, 2008).

In the present study, it was not possible to monitor the reduction of muscle glycogen during carcass cooling, or determine the $\mathrm{pH}$ and temperature of the carcasses before and during cooling, which limits, in part, the discussion of the results. However, by making a combinatorial analysis between the results obtained and those relative to the evaluation of the carcasses and meat quality published by Cruz et al. (2015a, 2015b), it is possible to assume that the concentrate and babassu mesocarp meal levels did not influence the stocks of muscle glycogen to the point of modifying the meat quality, since the shear strength of the muscle fiber, the coloration and the liquid-retention of the meat were similar among the experimental diets, as a result of the similar energy intake and animal performance (CRUZ et al., 2014), as well as the similar carcass fat cover, which is responsible for the protection of the carcass against the shortening of the muscle fibers by the cold, which reduces the meat tenderness (FELÍCIO, 1997). It should be noted that the muscle glycogen values verified can be considered low, which is because their quantification took place after the rigor mortis, in which low levels of glycogen are expected (ROÇA; SERRANO, 1995).

The liver and muscle ether extract content of the liver was not changed by the concentrate and babassu mesocarp bran levels (Table 2). The extra glucose that continuously penetrates the cells is stored in the form of glycogen or converted into lipids, and it is preferably stored as glycogen, until the cells have stored sufficient amounts to provide 
energy to the needs of the organism, for a period of 12 to 24 hours. When the cells that store glycogen (primarily liver and muscle cells) approach saturation with glycogen, the additional glucose is converted to lipids in the liver and muscle adipose cells and stored as fat (HALL, 2011). Net glucose production from the liver is closely correlated with overall metabolizable energy intake, the most important precursor is propionate but significant contributions may be made from glycerol, lactate and the glucogenic amino acids (REYNOLDS, 1995). In the present study the total digestible nutrients intake did not differ among treatments (CRUZ et al., 2014), which can explain the results obtained for liver and muscle ether extract content. The results of the present study were similar to those obtained by Miotto et al. (2012), who did not verify differences for the ether extract content of the meat of young bulls fed babassu mesocarp bran levels, in which the observed values were $2.4 \%, 2.2 \%, 2.3 \%$, $2.0 \%$ and $1.9 \%$ for the babassu mesocarp bran levels $0 \%, 25 \%, 50 \%, 75 \%$ and $100 \%$, respectively. With regard to the concentrate levels, the results of the present study were similar to those obtained by Duarte (2010), who verified that increasing the concentrate from 40 to $80 \%$ did not change the ether extract content (14.41\% vs $14.55 \%)$ of the meat. Likewise, Bren (2003), evaluating the dietary concentrate levels of $0.8 \%, 1.1 \%$ and $1.4 \%$ of the body weight, did not verify alteration in the ether extract content $(12.68 \%, 13.70 \%$ and $12.57 \%$, respectively) in the meat of feedlot-finished young bulls.

The moisture, crude protein and mineral matter contents were not changed by the levels of concentrate and babassu mesocarp bran (Table 2 ). These results were partially similar to those found by Miotto et al. (2012), who verified that the moisture and crude protein contents of the meat were not significantly modified by the increase in the babassu mesocarp bran level in the diet of confined young bulls. However, these authors verified increase in the mineral content of the meat as the babassu mesocarp bran content in the diet was increased, which was attributed to the greater mineral content of the by-product in relation to the corn grain, in which the mineral level of the diet increased by $22.6 \%$ from the lowest to the highest level of inclusion of the babassu mesocarp bran. In the present study, the inclusion of $35 \%$ of babassu mesocarp bran caused a variation of $15.5 \%$ and $18.5 \%$ in the mineral content for the lowest and the highest proportions of concentrate in the diet, respectively, which might have been sufficient for significant alterations regarding the mineral content of the meat.

The values found for the concentrations of moisture, crude protein and mineral matter were close to the results obtained by Miotto et al. (2012), who verified crude protein and mineral matter values varying from $22.5 \%$ to $23.4 \%$ and $3.6 \%$ to $3.4 \%$, respectively. According to Lawrie (2005), the meat presents on average $75 \%$ moisture, $19 \%$ protein, 3.5\% non-protein soluble substances and $2.5 \%$ fat, but these percentages can be changed by several factors such as sex, diet, among others. On the other hand, concerning the concentrate levels, the results obtained herein were similar to those found by Duarte (2010), who verified that the increase in the level of concentrate from $40 \%$ to $80 \%$ did not change the moisture $(53.15 \%$ vs $53.04 \%)$, crude protein $(24.82 \%$ vs $24.69 \%)$ or ash $(7.62 \%$ vs $7.70 \%$ ) contents of the meat. Corroborating this, Bren (2003), evaluating the levels of concentrate of $0.8 \%, 1.1 \%$ and $1.4 \%$ of the body weight, did not verify alterations for the moisture $(72.67 \%, 71.59 \%$ and $73.01 \%$, respectively), crude protein $(12.61 \%$, $13.04 \%$ and $12.93 \%$, respectively) or ash $(1.04 \%$, $1.08 \%$ and $1.08 \%$, respectively) contents of the meat from confined young bulls.

\section{Conclusions}

Inclusion of $35 \%$ babassu mesocarp bran in diets with a high level of concentrate does not induce hyperkeratinization of the ruminal papillae, as well 
as does not change the amount of muscle and liver glycogen or the chemical characteristics of the meat of Nellore young bulls, allowing for the production of meat with appropriate quality standards to commercialization.

Changing the proportion of concentrate in the diet from $65 \%$ to $71 \%$ in the finishing of feedlot Nellore young bulls does not alter the keratinization of the ruminal papillae, liver and muscle glycogen or the chemical characteristics of the meat.

\section{References}

ALVES, D. D.; TONISSI, R. H. de; GOES, B. de; MANCIO, A. B. Maciez da carne bovina. Ciência Animal Brasileira, Goiânia, v. 6, n. 3, p. 135-149, 2005.

ASSOCIATION OF OFFICIAL ANALYTICAL CHEMISTS - AOAC. Official methods of analysis. 16. ed. Arlington: AOAC International, 1995, $1025 \mathrm{p}$.

BREN, L. Desempenho e características de carcaça de bovinos jovens terminados com diferentes níveis de concentrado na dieta. 2003. Dissertação (Mestrado em Ciência Animal Tropical) - Universidade Federal do Tocantins, Araguaína.

CAFE, L. M.; ROBINSON, D. L.; FERGUSON, D. M.; GEESINK, G. H.; GREENWOOD, P. L. Temperament and hypothalamic-pituitary-adrenal axis function are related and combine to affect growth, efficiency, carcass, and meat quality traits in Brahman steers. Domestic Animal Endocrinology, New York, v. 40, n. 4 p. 230-240, 2011.

CASALI, A. O.; DETMAN, E.; VALADARES FILHO, S. C.; PEREIRA, J. C.; HENRIQUES, L. T.; FREITAS, S. G.; PAULINO, M. F. Influência do tempo de incubação e do tamanho de partículas sobre os teores de compostos indigestíveis em alimentos e fezes bovinas obtidos por procedimentos in situ. Revista Brasileira de Zootecnia, Viçosa, MG, v. 37, n. 2, p. 335-342, 2008.

CASTRO, A. K. M. de; ZANETTI, M. A. Estudo da inclusão de fibra na dieta de bezerros da raça Holandesa. Revista Brasileira de Zootecnia, Viçosa, MG, v. 27, n. 6, p. 1193-1198, 1998.

CHURCH, D. C. Fisiologia digestiva y nutrition de los rumiantes. Zaragoza: Acribia, 1974. 379p.

COCHRAN, R. C.; ADAMS, D. C.; WALLACE, J. D.; GALYEAN, M. L. Predicting digestibility of different diets with internal markers: evaluation of four potential markers. Journal of Animal Science, Champaign, v. 63, n. 5, p. 1476-1483, 1986.

COSTA, S. F.; PEREIRA, M. N.; MELO, L. Q.; CALARI, M. V.; CHAVES, M. L. Alterações morfológicas induzidas por butirato, propionato e lactato sobre a mucosa ruminal e epiderme de bezerros. II. Aspectos ultra-estruturais. Arquivo Brasileiro de Medicina Veterinária e Zootecnia, Belo Horizonte, v. 60, n. 1, p. 10-18, 2008.

CRUZ, R. S. da; ALEXANDRINO, E.; MISSIO, R. L.; NEIVA, J. N. M.; RESTLE, J.; MELO, J. C.; SOUSA JÚNIOR, A. de.; RESENDE, J. M. de. Feeding behaviors of feedlot bulls fed concentrate levels and babassu mesocarp bran. Revista Brasileira de Zootecnia, Viçosa, MG, v. 41, n. 7, p. 1727-1736, 2012.

CRUZ, R. S. da; ALEXANDRINO, E.; MISSIO, R. L.; NEIVA, J. N. M.; RESTLE, J.; MELO, J. C.; PAULA NETO, J. J.; SILVA, D. P.; DUARTE, T. D.; SILVA, A. A. M. Características das carcaças e carne de tourinhos Nelore alimentados com níveis de concentrado e farelo do mesocarpo de babaçu. Arquivo Brasileiro de Medicina Veterinária e Zootecnica, Belo Horizonte, v. 67, n. 1, p. 299-308, 2015b.

CRUZ, R. S. da; ALEXANDRINO, E.; MISSIO, R. L.; RESTLE, J.; MELO, J. C.; PAULA NETO, J. J. de; NEIVA, J. N. M.; MENDES FILHO, G. de. O.; SOUSA JÚNIOR, A. de; DUARTE, T. D.; RESENDE, J. M. de; MARINHO, A. A. Desempenho bioeconômico de tourinhos alimentados com níveis de concentrado e farelo do mesocarpo de babaçu. Semina: Ciências Agrárias, Londrina, v. 35, n. 4, p. 2159-2154, 2014.

CRUZ, R. S. da; ALEXANDRINO, E.; MISSIO, R. L.; RESTLE, J.; MELO, J. C.; PAULA NETO, J. J. de; SILVA, A. A. M.; SILVA, D. P. da. Níveis de concentrado e farelo do mesocarpo de babaçu sobre as características da carcaça de tourinhos confinados. Bioscience Journal, Uberlândia, v. 31, n. 1, p. 73-86, 2015a.

DI MARCO, O. N.; BARCELLOS, O. J.; COSTA, E. C. Crescimento de bovinos de corte. Porto Alegre: UFRGS, 2007. $276 \mathrm{p}$.

DUARTE, M. de. S. Desempenho e qualidade da carne em novilhas de corte alimentadas com dois níveis de concentrado e proteína não degradável no rúmen e influencia da maturidade fisiológica sobre os parâmetros qualitativos da carcaça e carne de bovinos. 2010. Dissertação (Mestrado em Zootecnia) - Universidade Federal de Viçosa, Viçosa, MG.

FELÍCIO, P. E. de. Fatores ante et post mortem que influenciam na qualidade da carne bovina. In: PEIXOTO, A. M.; MOURA, J. C. de; FARIA, V. P. de. (Ed.). Produção do novilho de corte. Piracicaba: FEALQUSP, 1997. p. 79-97. 
FERGUSON, D. M.; WARNER, R. D. Have we underestimated the impact of pre-slaughter stress on meat quality in ruminants?. Meat Science, New York, v. 80, n. 1, p. 12-19, 2008.

GOODLAD, R. A. Some effects of diet on the mitotic index and the cell cycle of the ruminal epithelium of sheep. Quarterly Journal of Experimental Physiology, Dublin, v. 66, n. 4, p. 487-299, 1981.

GREENWOOD, R. H.; MORRIL, J. L.; TITGEMEYER, E. E.; KENNEDY, G. A. A new method of measuring diet abrasion and its effect on the development of the forestomach. Journal of Dairy Science, Champaign, v. 80, n. 10, p. 2534-2541, 1997.

HALL, J. E. Metabolismo dos carboidratos e formação do trifosfato de adenosina. In: GUYTON, A. C.; HALL, J. E. (Ed.). Tratado de fisiologia médica. Rio de Janeiro: Elsevier, 2011. p. 851-860.

HANDEL, V. E. Estimation of glycogen in small amounts of tissue. Analytical Biochemistry, New York, v. 11, n. 2, p. $256-265,1965$.

HENRIQUES, G. S.; UNICKI, P. C.; IBÃNEZ, F. S.; SIMEONE, M. L. F. A farinha do mesocarpo do babaçu (Orbignya phalerata) como componente de uma mistura protéica em dieta semipurificada e seus reflexos sobre a colesterolemia e a trigliceridemia em ratos. Revista do Médico Residente, Curitiba, v. 11, n. 2, p. 61-68, 2009.

JENSEN, R.; DEANE, H. M.; COOPER, L. J.; MILLER, V. A.; GRAHAM, W. R. The rumenitis-liver abscess complex in beef cattle. American Journal of Veterinary Research, Schaumburg, v. 15, n. 55, p. 277-282, 1954.

LAWRIE, R. A. Ciência da carne. 6. ed. Porto Alegre: Artmed, 2005. 384 p.

LIMA, H. M.; BARCELOS, M. de. F. P.; SOUZA, R. V. de; MORAIS, A. R. de. Influência das formas de carboidratos no treinamento físico e na supercompensação glicogênica de ratos. Ciência e Agrotecnologia, Lavras, v. 27, n. 3, p. 605-617, 2003.

MARÍA, G. A.; VILLARROEL, M.; SANUDO, C.; OLLETAA, J. L.; GEBRESENBETB, G. Effect of transport time and ageing on aspects of beef quality. Meat Science, New York, v. 65, n. 4, p. 1335-1340, 2003.

MIOTTO, F. R. C.; RESTLE, J.; NEIVA, J. N. M.; CASTRO, K. J. de; SOUSA, L. F.; SILVA, R. de. O. da; FREITAS, B. B. de; LEÃO, J. P. Replacement of corn by babassu mesocarp bran in diets for feedlot young bulls. Revista Brasileira de Zootecnia, Viçosa, MG, v. 42, n. 3, p. 213-219, 2013.
MIOTTO, F. R. C.; RESTLE, J.; NEIVA, J. N. M.; RESENDE, P. L. de P.; LAGE, M. E.; PRADO, C. S. Farelo de mesocarpo de babaçu (Orbygnia sp.) na terminação de bovinos: composição física da carcaça e qualidade da carne. Ciência Rural, Santa Maria, v. 42, n. 7, p. 1271-1277, 2012.

MUCHENJE, V.; DZANA, K.; CHIMONYO, M.; STRYDOM, P. E.; HUGO, A.; RAATS, J. G. Some biochemical aspects pertaining to beef eating quality and consumer health: A review. Food Chemistry, New York, v. 112, n. 2, p. 279-289, 2009.

NATIONAL RESEARCH COUNCIL - NRC. Nutrient requirements of beef cattle. $7^{\text {th }}$ ed. Washington: National Academy Press, 1996. 242 p.

PAVLAK, M. C. M.; ZUNIGA, A. D.; ABREU-LIMA, T. L. de; PINEDO, A. A.; CARREIRO, S. C.; FLEURY, C. S.; SILVA, D. L. Aproveitamento da farinha do mesocarpo do babaçu (Orbignya martiana) para obtenção de etanol. Evidência, Joaçaba, v. 7, n. 1, p. 7-24, 2007.

RESENDE JÚNIOR, J. C.; ALONSO, L. S.; PEREIRA, M. N.; ROCA, M. G.; DUBOC, M. V.; OLIVEIRA, E. C.; MELO, L. Q. Effect of the feeding pattern on rumen wall morphology of cows and sheep. Brazilian Journal of Veterinary Research and Animal Science, São Paulo, v. 43, n. 4, p. 526-536, 2006.

REYNOLDS, C. K. Quantitative aspects of liver metabolism in ruminants. In: ENGELHARDT, W. VON, LEONHARD-MAREK, S., BREVES, G.; GIESECKE, D. (Ed.). Ruminant physiology: digestion, metabolism, growth and reproduction: proceedings of the eighth international symposium on ruminant physiology. Stuttgart: Ferdinand Enke Verlag, 1995. p. 351-371.

ROÇA, R. O.; SERRANO, A. M. Influência do banho de aspersão ante-mortem em parâmetros bioquímicos e na eficiência da sangria da carne bovina. Pesquisa Agropecuária Brasileira, Brasília, v. 30, n. 8, p. $1107-$ 1115, 1995.

RODRIGUES FILHO, M.; MANCIO, A. B.; GOMES, S. T.; SILVA, F. F. da; LANA, R. de. P.; RODRIGUES, N. E. B.; SOARES, C. A.; VELOSO, C. M. Avaliação econômica do confinamento de novilhos de origem leiteira, alimentados. Revista Brasileira de Zootecnia, Viçosa, MG, v. 31, n. 5, p. 2055-2069, 2002.

SILVA, N. R. da; FERREIRA, A. C. H.; FATURI, C.; SILVA, G. F. da; MISSIO, R. L.; NEIVA, J. N. M.; ARAÚJO, V. L. de; ALEXANDRINO, E. Desempenho em confinamento de bovinos de corte, castrados ou não, alimentados com teores crescentes de farelo do mesocarpo de babaçu. Ciência Rural, Santa Maria, v. 42, n. 10, p. $1882-1887,2012$. 
SNIFFEN, C. J.; O'CONNOR, J. D.; VAN SOEST, P. J.; FOX, D. G.; RUSSEL, J. B. A net carbohydrate and protein system for evaluating cattle diets: II. Carbohydrate and protein availability. Journal of Animal Science, Champaign, v. 70, n. 12, p. 3562-3577, 1992.

STALKER, M. A.; HAYES, M. A. Liver and biliary system. In: MAXIE, M. G. Pathology of domestic animals. $5^{\text {th }}$ ed. New York: Elselvier, 2007. v. 2, p. 298357.

VAN SOEST, P. J.; ROBERTSON, J. B.; LEWIS, B. A. Methods for dietary fiber, neutral detergent fiber, and nonstarch polyssacarides in relation to animal nutrition. Journal of Animal Science, Champaign, v. 74, n. 10, p. 3583-3597, 1991.
WARNER, R. G.; PROTER, J. C.; SLACK, T. S. Calf starte formulation for neonatal calves fed no hay. In: CORNELL NUTRITION CONFERENCE, 1973, Ithaca. Proceedings... Ithaca: Cornell University, 1973. p. 116122.

YASHPAL, M.; KUMARI, U.; MITTAL, S.; MITTAL, A. K. Histochemical characterization of glycoproteins in the buccal epithelium of a catfish Rita rita. Acta Histochemica, New York, v. 109, n. 4, p. 285-303, 2007. 
